\title{
Hypermethylation and aberrant expression of Wnt antagonist secreted frizzled-related protein 1 in gastric cancer
}

\author{
Cheng-Hai Zhao, Xian-Min Bu, Ning Zhang
}

Cheng-Hai Zhao, Ning Zhang, Department of Pathophysiology, School of Basic Medicine, China Medical University, Shenyang 110001, Liaoning Province, China

Xian-Min Bu, Department of General Surgery, the Second Affiliated Hospital, China Medical University, Shenyang 110004, Liaoning Province, China

Supported by Liaoning Education Divison Foundation, No. 05L557

Correspondence to: Dr. Cheng-Hai Zhao, Department of Pathophysiology, School of Basic Medicine, China Medical University, Shenyang 110001, Liaoning Province,

China.zhaochenghai1@sina.com

Telephone: +86-24-23256666-5362

Received: 2006-12-16

Accepted: 2007-01-26 tumor metastasis in primary gastric cancer.

(c) 2007 The WJG Press. All rights reserved.

Key words: Secreted frizzled-related protein 1; Wnt; Hypermethylation

Zhao $\mathrm{CH}$, Bu XM, Zhang N. Hypermethylation and aberrant expression of Wnt antagonist secreted frizzled-related protein 1 in gastric cancer. World J Gastroenterol 2007; 13(15): 2214-2217

http://www.wjgnet.com/1007-9327/13/2214.asp

\begin{abstract}
AIM: To identify the methylation of secreted frizzledrelated protein 1 (SFRP1) in gastric cancer and to investigate the aberrant expression of SFRP1 and its correlation with the clinical pathological features of patients.
\end{abstract}

METHODS: We determined SFRP1 methylation and SFRP1 mRNA expression in 3 gastric cancer cell lines SGC-7901, BGC-823, HGC-27, from 52 primary gastric cancer specimens and matched tumor adjacent tissue specimens by methylation-specific (MSP) PCR and RTPCR respectively. Fisher's exact test was used to analyze the statistical association between clinical pathological data and aberrant expression of SFRP1.

RESULTS: In 3 cancer cell lines, BGC-823 and HGC-27 had methylated SFRP1 and lost SFRP1 mRNA expression. After treatment of BGC-823 and HGC-27 with the demethylating agent, 5-aza-2'-deoxycytidine, SFRP1 was re-expressed. In 52 primary gastric cancer specimens and matched tumor adjacent tissue specimens, hypermethylation of SFRP1 was detected in $23(44 \%)$ and $8(15 \%)$ specimens respectively $\left(\chi^{2}=10.34\right.$, $P<0.01)$. Loss of SFRP1 expression was detected in $17(33 \%)$ and $6(12 \%)$ specimens respectively $\left(\chi^{2}=6.75\right.$, $P<0.01)$. There was a significant correlation between SFRP1 hypermethylation and SFRP1 expression loss. SFRP1 expression was also correlated significantly with tumor stage and lymph node status, but not with patient sex, age and histological type.

CONCLUSION: SFRP1 inactivation is a common and early event caused mainly by hypermethylation in gastric cancer. SFRP1 expression loss may be correlated with

\section{INTRODUCTION}

Carcinogenesis is a complex process involving a series of genetic and epigenetic changes. Aberrant methylation is recognized as an important pathway leading to gene silencing. Hypermethylation in $\mathrm{CpG}$ islands and silencing of tumor-related genes in human cancer have been the focus of study in the last decade.

Secreted frizzled-related protein 1 (SFRP1) found in 1987 by several different groups ${ }^{[1-3]}$, contains a cysteinerich domain (CRD) which share 30\%-50\% sequence similarity with those of Wnt receptor frizzled proteins. Through the CRD, SFRP1 can antagonize Wnt signaling by interacting with Wnt ligand. As Wnt signaling pathway plays an important role both in embryo development and in proliferation, differentiation and apoptosis in adult tissues. Thus aberrant activation of Wnt pathway may induce tumorigenesis. As a Wnt inhibitor, SFRP1 downregulation caused by hypermethylation has been found in several kinds of cancer ${ }^{[4-8]}$.

In this study, we detected the methylation status and aberrant expression of SFRP1 in gastric cancer. We also analyzed the correlation between the expression of SFRP1 and clinical pathologic characteristics of primary gastric cancer.

\section{MATERIALS AND METHODS}

Cell lines, cancer and matched adjacent tissue samples

Human gastric cancer cell lines SGC-7901, BGC-823 and HGC-27 (From KUNKEN Bio-reagent Corp. Shanghai, China) were cultured in RPMI 1640 supplemented with $10 \%$ fetal bovine serum, penicillin (100 IU/mL), and streptomycin $(100 \mu \mathrm{g} / \mathrm{mL})$. Primary gastric cancer and 

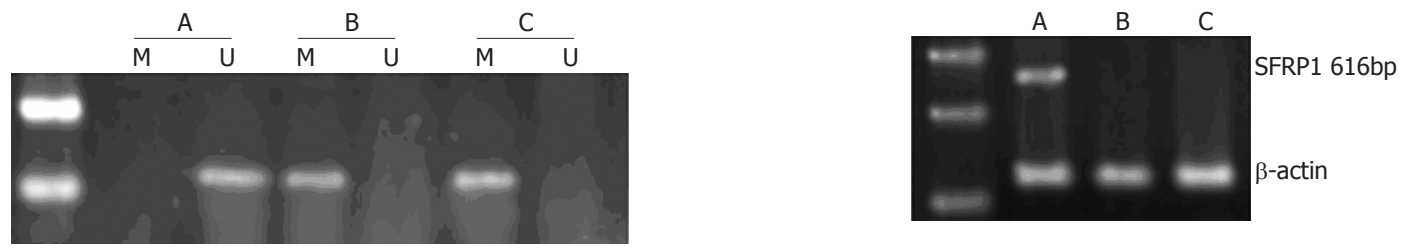

Figure 2 Expression of SFRP1 mRNA in SGC-7901 (A) but not in BGC-823 (B) and HGC-27 (C).
Figure 1 Hypermethylation of SFRP1 in BGC-823 (B) and HGC-27 (C) but not in SGC-7901 (A). M: methylated; U: unmethylated.

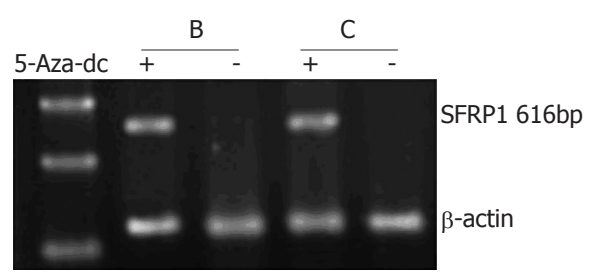

Figure 3 Expression of SFRP1 mRNA after treatment with 5-aza-2'-deoxycytidine in BGC-823 (B) and HGC-27 (C).

matched adjacent tissue samples were obtained from patients who underwent operation at the Second Affiliated Hospital, Chinese Medical University. The samples were frozen in liquid nitrogen immediately after surgery. Haematoxylin and eosin staining was used to confirm that cancer samples were consisted mostly of tumor cells and there were no tumor cell in tumor adjacent tissue samples.

\section{DNA and RNA extraction}

DNA was extracted by a standard phenol/chloroform extraction and ethanol precipitation procedure. RNA was isolated by TRIZOL (Takara Corp.) according to the protocols supplied by the manufacturer.

\section{Semi-quantitative reverse transcription-PCR}

RT-PCR was performed by Takala RNA PCR 3.0 Kit. cDNA was synthesized from $1 \mu \mathrm{g}$ SFRP1 RNA using random 9 primer and AMV reverse transcriptase. Cycle condition was 1 cycle at $30^{\circ} \mathrm{C}$ for $10 \mathrm{~min}$, at $42^{\circ} \mathrm{C}$ for 25 $\min$, at $99^{\circ} \mathrm{C}$ for $5 \mathrm{~min}$ and at $5^{\circ} \mathrm{C}$ for $5 \mathrm{~min}$. For PCR, the SFRP1 primer sequences ${ }^{[7]}$ are $\mathrm{F}$ (5'-TCTACACCAAGC CACCTCAG-3') and R (5'-CAGTCACCCCATTCTTCA GG-3'). Cycle condition was 1 cycle at $94^{\circ} \mathrm{C}$ for $2 \mathrm{~min} ; 30$ cycles at $94^{\circ} \mathrm{C}$ for $30 \mathrm{~s}$, at $60^{\circ} \mathrm{C}$ for $30 \mathrm{~s}$ and at $72^{\circ} \mathrm{C}$ for 2 $\min$.

\section{Methylation-specific PCR}

The methylation status of SFRP1 was detected by GENMED MSP Kit (GENMED, Shanghai, China). The procedure was performed according to its protocol. The primers $^{[7]}$ for methylated sequence of SFRP1 are F (5' -TGTAGT'T'T'TCGGAGT'TAGTGTCGCGC-3') and R (5' -CCTACGATCGAAAACGACGCGAACG-3’), and those for unmethylated sequences are F (5'-GT'T'T'TGTAGT'T'T 'TTGGAGT'TAGTGT'TGTGT-3') and R (5'-CTCAACCT ACAATCAAAAACAACACAAACA-3'). Cycle condition was 1 cycle at $95^{\circ} \mathrm{C}$ for $5 \mathrm{~min} ; 35$ cycles at $95^{\circ} \mathrm{C}$ for $30 \mathrm{~s}$, at $60^{\circ} \mathrm{C}$ for $30 \mathrm{~s}$ and at $72^{\circ} \mathrm{C}$ for $30 \mathrm{~s}$.
Table 1 Hypermethylation and expression loss of SFRP1 in primary gastric cancer and matched cancer adjacent tissue samples

\begin{tabular}{lccc}
\hline & $\boldsymbol{n}$ & Hypermethylation $(+)$ & Expression (-) \\
\hline Gastric cancer & 52 & 23 & 17 \\
Adjacent tissue & 52 & 8 & 6 \\
$P$ & & $\chi^{2}=10.34, P<0.01$ & $\chi^{2}=6.75, P<0.01$ \\
\hline
\end{tabular}

\section{5-aza-2'-deoxycytidine treatment}

Cells were seeded at a density of $3 \times 10^{4}$ cells $/ \mathrm{cm}^{2}$ in a four well plate on d 0 , and exposed to 5-aza-2'-deoxycytidine (Sigma, $1 \mu \mathrm{mol} / \mathrm{L}$ ) on d 1, 2, and 3. After each treatment, the cells were cultured in fresh medium. Control cells were incubated without the addition of 5-aza-2'-deoxycytidine. Cells were harvested in $\mathrm{d} 4$ for RNA extract.

\section{Statistical analysis}

Methylation and expression status of SFRP1 in primary pancreatic cancer and adjacent tissue samples were compared by $\chi^{2}$ test. Fisher's exact test was used to study the statistical association between clinical pathologic data and aberrant expression of SFRP1. Differences were considered statistically significant when $P$ values were less than 0.05 .

\section{RESULTS}

\section{Hypermethylation and expression of SFRP1 in gastric cancer cell lines}

Hypermethylation of SFRP1 was found in BGC-823 and HGC-27 by MSP (Figure 1). Expression of SFRP1 mRNA was detected in SGC-7901, but not in BGC-823 and HGC-27 (Figure 2). After treatment of BGC-823 and HGC-27 with the demethylating agent, 5-aza-2' -deoxycytidine, SFRP1 mRNA was re-expressed in BGC-823 and HGC-27 (Figure 3).

\section{Hypermethylation and expression of SFRP1 in primary gastric cancer and matched cancer adjacent tissue samples}

In 52 primary gastric cancer samples, hypermethylation of SFRP1 was detected in 23. In matched cancer adjacent tissue samples, 8 were found with SFRP1 hypermethylation. The hypermethylation rate in primary gastric cancer samples was significantly higher than that in matched cancer adjacent tissue samples $\left(\chi^{2}=10.34, P\right.$ $<0.01)$. Expression of SFRP1 mRNA was not found in 17 gastric cancer samples and 6 matched cancer adjacent tissue samples respectively. The difference was also significant $\left(\chi^{2}=6.75, P<0.01\right)$ (Table 1$)$. 
Table 2 Correlation of SFRP1 expression with SFRP1 hypermethylation and clinical pathologic patient data

\begin{tabular}{lllrc}
\hline Variable & Categorisation & $\boldsymbol{n}$ & SFRP1 (-) & $\boldsymbol{P}$ \\
\hline Sex & Male & 34 & 11 & 0.24 \\
Age at diagnosis & Female & 18 & 6 & \\
(yr) & $>50$ & 30 & 12 & 0.10 \\
Tumor stage1 & $\leqslant 50$ & 22 & 5 & \\
& T1 + T2 & 25 & 4 & 0.01 \\
Lymph node status & T3 + T4 & 27 & 13 & \\
& N0 + N1 & 36 & 8 & 0.02 \\
Histological type & N2+ N3 & 16 & 9 & \\
\multirow{4}{*}{ Methylation status } & Diffused & 31 & 12 & 0.13 \\
& Intestinal & 21 & 5 & \\
& Methylated & 28 & 13 & 0.02 \\
& Unmethylated & 24 & 4 & \\
\hline
\end{tabular}

${ }^{1}$ According to UICC: TNM classification of malignant tumors

\section{Correlation analysis of SFRP1 expression, SFRP1 hypermethylation and clinical pathologic data in primary gastric cancer}

Fisher's exact test was used to analyze the correlation between SFRP1 expression and SFRP1 methylation and other clinical pathologic patient data. A significant correlation was found $(P=0.02)$ between SFRP1 hypermethylation and SFRP1 expression loss. SFRP1 expression was also correlated significantly with tumor stage $(P=0.01)$ and lymph node status $(P=0.02)$, but not with patient sex, age, histological type (Table 2$)$.

\section{DISCUSSION}

Hypermethylation in promoter $\mathrm{CpG}$ islands and diminished expression have been reported to be present in a number of tumor-related genes in gastric cancer, including $p 16^{[9]}$, hMLH1 $^{[10]}$, E-cadherin $^{[11]}$, APC $^{[12]}$, MGMT $^{[13]}$, RASSF1A $^{[14]}$, DAP-kinase ${ }^{[15]}$, RUNX $^{[16]}$, GSTP1 ${ }^{[17]}$. In addition, many studies have shown that concurrent hypermethylation of multiple tumor-related genes in gastric cancer, is also termed CpG island methylator phenotype (CIMP). Recently, several other tumor-related genes have been reported with hypermethylation in $\mathrm{CpG}$ island in gastric cancer, such as $\mathrm{CHFR}^{[18]}, \mathrm{HLTF}^{[19]}, \mathrm{RIZ}^{[20]}, \mathrm{HRK}^{[21]}$, SOCS $-1^{[22]}, \mathrm{BNIP}^{[23]}$. The identification of genes targeted by hypermethylation may provide insights into the mechanisms underlying the inactivation of tumor suppressive pathways in gastric cancer.

Wnt signaling pathway plays an important role in cell proliferation, differentiation and apoptosis in adult tissues. Aberrant activation of Wnt signaling in tumorigenesis has been reported frequently. Overexpression of members of Wnt family, such as Wnt1, Wnt2 and Wnt3a, has been found in several kinds of human cancer ${ }^{[24-26]}$. Down-regulation of Wnt inhibitor DKK family has also been found in human cancer ${ }^{[27,28]}$. As another kind of Wnt inhibitor, SFRP1 may promote cell apoptosis ${ }^{[2]}$. Additionally, the SFRP1 gene has been found at $8 \mathrm{p} 11.2$, a site of frequent loss of heterozygosity, so it may be a putative tumor suppressor gene. SFRP1 down-regulation has also been found in several kinds of human in recent years. Most of these reports showed that SFRP1 expression loss mainly caused by promoter hypermethylation is an important epigenetic gene silencing mechanism.

In this study, we analyzed the expression status of SFRP1 in gastric cancer. Our results showed that primary gastric cancer had SFRP1 expression loss which was significantly correlated with SFRP1 hypermethylation. The hypermethylation rate in primary gastric cancer samples was significantly higher than that in tumor adjacent tissue samples, suggesting SFRP1 hypermethyaltion and subsequent expression loss occur early and play an important role in gastric cancer. At the same time, SFRP1 expression loss was significantly correlated with tumor stage and lymph node status, indicating that SFRP1 expression loss might be associated with poor prognosis in gastric cancer.

As we know, Wnt signaling is divided into canonical pathway Wnt/ $\beta$-catenin and non-canonical pathway, including planar cell polarity pathway and $\mathrm{Wnt} / \mathrm{Ca}^{2+}$ pathway. As we did not measure the level of $\beta$-catenin, we could not determine the pathway through which SFRP1 expression loss take part in the gastric carcinogenesis. The detailed mechanism still needs more studies. Because the epigenetic alteration usually is reversible, demethylating drugs may be used in the treatment of gastric cancer.

\section{COMMENTS}

\section{Background}

Wnt signaling pathway plays an important role in cell proliferation, differentiation and apoptosis in adult tissues. Aberrant activation of Wnt signaling in tumorigenesis has been reported frequently. As a Wnt inhibitor, SFRP1 downregulation has been $\mathrm{s}$ found in several kinds of human cancer in recent years.

\section{Innovations and breakthroughs}

In this study, we analyzed the methyaltion and expression status of SFRP1 in gastric cancer. SFRP1 inactivation was found to be a common and early event caused mainly by hypermethylation in gastric cancer.

\section{Application}

Because many tumor-related genes are methyalted in gastric cancer, demethylating drugs may be used in treatment of gastric cancer.

\section{Peer review}

The authors examined SFRP1 methylation and SFRP1 mRNA expression in 3 gastric cancer cell lines, 52 primary gastric cancers and matched adjacent tissues by methylation-specific PCR and RT-PCR, respectively. Two of the 3 cancer cell lines had methylated SFRP1 and lost mSFRP1 mRNA expression. Hypermethylation of SFRP1 was detected in 23 gastric cancers and 8 adjacent tissues, respectively. There was a significant correlation between SFRP1 hypermethylation and SFRP1 expression loss. The authors concluded that SFRP1 inactivation is a common and early event which is caused mainly by hypermethylation in gastric cancer.

\section{REFERENCE}

1 Finch PW, He X, Kelley MJ, Uren A, Schaudies RP, Popescu NC, Rudikoff S, Aaronson SA, Varmus HE, Rubin JS. Purification and molecular cloning of a secreted, Frizzledrelated antagonist of Wnt action. Proc Natl Acad Sci USA 1997; 94: $6770-6775$

2 Melkonyan HS, Chang WC, Shapiro JP, Mahadevappa M, Fitzpatrick PA, Kiefer MC, Tomei LD, Umansky SR. SARPs: a family of secreted apoptosis-related proteins. Proc Natl Acad Sci USA 1997; 94: 13636-13641 
3 Rattner A, Hsieh JC, Smallwood PM, Gilbert DJ, Copeland NG, Jenkins NA, Nathans J. A family of secreted proteins contains homology to the cysteine-rich ligand-binding domain of frizzled receptors. Proc Natl Acad Sci USA 1997; 94: 2859-2863

4 Ugolini F, Charafe-Jauffret E, Bardou VJ, Geneix J, Adélaïde J, Labat-Moleur F, Penault-Llorca F, Longy M, Jacquemier J, Birnbaum D, Pébusque MJ. WNT pathway and mammary carcinogenesis: loss of expression of candidate tumor suppressor gene SFRP1 in most invasive carcinomas except of the medullary type. Oncogene 2001; 20: 5810-5817

5 Caldwell GM, Jones C, Gensberg K, Jan S, Hardy RG, Byrd P, Chughtai S, Wallis Y, Matthews GM, Morton DG. The Wnt antagonist sFRP1 in colorectal tumorigenesis. Cancer Res 2004; 64: 883-888

6 Takada T, Yagi Y, Maekita T, Imura M, Nakagawa S, Tsao SW, Miyamoto K, Yoshino O, Yasugi T, Taketani Y, Ushijima T. Methylation-associated silencing of the Wnt antagonist SFRP1 gene in human ovarian cancers. Cancer Sci 2004; 95: 741-744

7 Zou H, Molina JR, Harrington JJ, Osborn NK, Klatt KK, Romero Y, Burgart LJ, Ahlquist DA. Aberrant methylation of secreted frizzled-related protein genes in esophageal adenocarcinoma and Barrett's esophagus. Int I Cancer 2005; 116: $584-591$

8 Lodygin D, Epanchintsev A, Menssen A, Diebold J, Hermeking H. Functional epigenomics identifies genes frequently silenced in prostate cancer. Cancer Res 2005; 65: 4218-4227

9 Shim YH, Kang GH, Ro JY. Correlation of p16 hypermethylation with $\mathrm{p} 16$ protein loss in sporadic gastric carcinomas. Lab Invest 2000; 80: 689-695

10 Fleisher AS, Esteller M, Wang S, Tamura G, Suzuki H, Yin J, Zou TT, Abraham JM, Kong D, Smolinski KN, Shi YQ, Rhyu MG, Powell SM, James SP, Wilson KT, Herman JG, Meltzer SJ. Hypermethylation of the hMLH1 gene promoter in human gastric cancers with microsatellite instability. Cancer Res 1999; 59: 1090-1095

11 Machado JC, Oliveira C, Carvalho R, Soares P, Berx G, Caldas C, Seruca R, Carneiro F, Sobrinho-Simöes M. E-cadherin gene (CDH1) promoter methylation as the second hit in sporadic diffuse gastric carcinoma. Oncogene 2001; 20: 1525-1528

12 Tsuchiya T, Tamura G, Sato K, Endoh Y, Sakata K, Jin Z, Motoyama T, Usuba O, Kimura W, Nishizuka S, Wilson KT, James SP, Yin J, Fleisher AS, Zou T, Silverberg SG, Kong D, Meltzer SJ. Distinct methylation patterns of two APC gene promoters in normal and cancerous gastric epithelia. Oncogene 2000; 19: 3642-3646

13 Oue N, Shigeishi H, Kuniyasu H, Yokozaki H, Kuraoka K, Ito R, Yasui W. Promoter hypermethylation of MGMT is associated with protein loss in gastric carcinoma. Int I Cancer 2001; 93: 805-809

14 Byun DS, Lee MG, Chae KS, Ryu BG, Chi SG. Frequent epigenetic inactivation of RASSF1A by aberrant promoter hypermethylation in human gastric adenocarcinoma. Cancer Res 2001; 61: 7034-7038

15 Satoh A, Toyota M, Itoh F, Kikuchi T, Obata T, Sasaki Y, Suzuki H, Yawata A, Kusano M, Fujita M, Hosokawa M, Yanagihara K, Tokino T, Imai K. DNA methylation and histone deacetylation associated with silencing DAP kinase gene expression in colorectal and gastric cancers. $\mathrm{Br} J$ Cancer 2002; 86: 1817-1823

16 Li QL, Ito K, Sakakura C, Fukamachi H, Inoue Ki, Chi XZ, Lee KY, Nomura S, Lee CW, Han SB, Kim HM, Kim WJ, Yamamoto H, Yamashita N, Yano T, Ikeda T, Itohara S, Inazawa J, Abe T, Hagiwara A, Yamagishi H, Ooe A, Kaneda A, Sugimura T, Ushijima T, Bae SC, Ito Y. Causal relationship between the loss of RUNX3 expression and gastric cancer. Cell 2002; 109: 113-124

17 Kang GH, Lee S, Kim WH, Lee HW, Kim JC, Rhyu MG, Ro JY. Epstein-barr virus-positive gastric carcinoma demonstrates frequent aberrant methylation of multiple genes and constitutes $\mathrm{CpG}$ island methylator phenotype-positive gastric carcinoma. Am J Pathol 2002; 160: 787-794

18 Satoh A, Toyota M, Itoh F, Sasaki Y, Suzuki H, Ogi K, Kikuchi T, Mita H, Yamashita T, Kojima T, Kusano M, Fujita M, Hosokawa M, Endo T, Tokino T, Imai K. Epigenetic inactivation of CHFR and sensitivity to microtubule inhibitors in gastric cancer. Cancer Res 2003; 63: 8606-8613

19 Hibi K, Nakayama H, Kanyama Y, Kodera Y, Ito K, Akiyama S, Nakao A. Methylation pattern of HLTF gene in digestive tract cancers. Int J Cancer 2003; 104: 433-436

20 Oshimo Y, Oue N, Mitani Y, Nakayama H, Kitadai Y, Yoshida $\mathrm{K}$, Chayama K, Yasui W. Frequent epigenetic inactivation of RIZ1 by promoter hypermethylation in human gastric carcinoma. Int J Cancer 2004; 110: 212-218

21 Obata T, Toyota M, Satoh A, Sasaki Y, Ogi K, Akino K, Suzuki H, Murai M, Kikuchi T, Mita H, Itoh F, Issa JP, Tokino T, Imai K. Identification of HRK as a target of epigenetic inactivation in colorectal and gastric cancer. Clin Cancer Res 2003; 9: 6410-6418

22 To KF, Chan MW, Leung WK, Ng EK, Yu J, Bai AH, Lo AW, Chu SH, Tong JH, Lo KW, Sung JJ, Chan FK. Constitutional activation of IL-6-mediated JAK/STAT pathway through hypermethylation of SOCS-1 in human gastric cancer cell line. Br J Cancer 2004; 91: 1335-1341

23 Murai M, Toyota M, Suzuki H, Satoh A, Sasaki Y, Akino K Ueno M, Takahashi F, Kusano M, Mita H, Yanagihara K, Endo $\mathrm{T}$, Hinoda $\mathrm{Y}$, Tokino T, Imai K. Aberrant methylation and silencing of the BNIP3 gene in colorectal and gastric cancer. Clin Cancer Res 2005; 11: 1021-1027

24 Blavier L, Lazaryev A, Dorey F, Shackleford GM, DeClerck YA. Matrix metalloproteinases play an active role in Wnt1induced mammary tumorigenesis. Cancer Res 2006; 66: 2691-2699

25 Katoh M. WNT2 and human gastrointestinal cancer (review). Int J Mol Med 2003; 12: 811-816

26 Verras M, Brown J, Li X, Nusse R, Sun Z. Wnt3a growth factor induces androgen receptor-mediated transcription and enhances cell growth in human prostate cancer cells. Cancer Res 2004; 64: 8860-8866

27 Byun T, Karimi M, Marsh JL, Milovanovic T, Lin F, Holcombe RF. Expression of secreted Wnt antagonists in gastrointestinal tissues: potential role in stem cell homeostasis. I Clin Pathol 2005; 58: 515-519

28 Katoh Y, Katoh M. Comparative genomics on DKK2 and DKK4 orthologs. Int J Mol Med 2005; 16: 477-481

S- Editor Liu Y L- Editor Wang XL E- Editor Che YB 